Article

\title{
Synthesis of a Diamino Substituted Terphenyldivinyl Chromophore
}

\author{
Zhen-Ting Du ${ }^{1}{ }^{{ }^{*}}$, Ru Liu ${ }^{1}$, Jun-Ru Wang ${ }^{1}$ and An-Pai $\mathrm{Li}^{2}{ }^{2} *$
}

1 College of Sciences, Northwest A\&F University, Yangling, Shaanxi 712100, China;

E-mails: liuru75@gmail.com (R.L.),wangjr07@163.com (J-R.W.)

2 Synthetics Technologica Pte Ltd, 3 Phillip Street, \#18-00 Commerce Point, 048693, Singapore; E-mail: anpaili@sina.com (A-P.L.)

* Author to whom correspondence should be addressed; E-mail duzt@nwsuaf.edu.cn; Tel.: +86-29-87092226; Fax: +86-29-87092226

Received: 24 April 2009; in revised form: 1 June 2009 / Accepted: 3 June 2009 /

Published: 10 June 2009

\begin{abstract}
E,E)-1,4-bis(4'-aminostyryl)-2,5-bis(octyloxy)-benzene (6) and its derivative (E,E)-1,4-bis(4'-acetamidostyryl)-2,5-bis(octyloxy)-benzene (7) were synthesized and characterized after alkylation, bromomethylation, Horner-Emmons reaction and reduction from hydroquinone. In order to gain more molecular electronic data, HOMO and LUMO of compound 6 have been calculated by Gaussian $03 \mathrm{~W}$.
\end{abstract}

Keywords: chromophore; energy transfer; synthesis; terphenyldivinyl

\section{Introduction}

As we all know, photosynthesis is the most important way on which all the lives in our planet depend directly or indirectly. Now, photosynthesis has been understood as a series sequence of energy and charge transfer in plants or microorganisms. Some photo-voltaic processes are designed based on mechanism of photosynthesis [1-3]. However, there is still a necessity to design and discover new chromophores to meet the need in research of charge or energy transfer. At the same time, organic light-emitting devices (OLED) employing organic chromophores as emitters have been the focuses of considerable interest because of their possible application as display for mobile phones, personal computers, and television [4,5]. Oligophenylvinyl [6-9] is a common chromophore used in study of 
energy transfer or in OLED. A diamino substituted oligophenylvinyl (E,E)-1,4-bis(4'-aminostyryl)-2,5dimethoxybenzene (BDB) have been reported by Wu [10], but the synthetic process was not published. As shown in Figure 1, we have designed a polymer consist of terphenyldivinyl and perylene tetracarboxylic anhydride [11-16] which through double imide bond in our future research.

Figure 1. Designed polymer with terphenyldivinyl and perylene moiety.

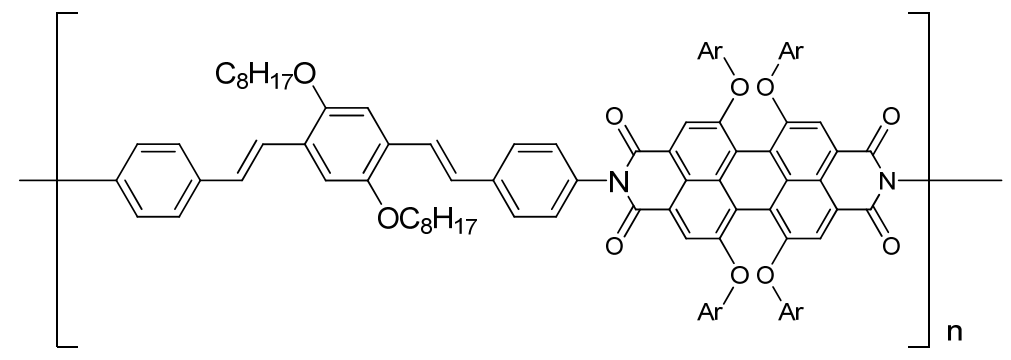

Because of the low solubility of perylene moiety in common solvent, the long carbon chain was introduced. So oligophenylvinyl chromophore $\mathbf{6}$ and its acetylated derivative $\mathbf{7}$ were devised and synthesized. Herein, we describe the synthesis of these series chromophores and the results of theoretical computation.

\section{Results and Discussion}

As shown in Scheme 1, the long alkyl chain ether in the middle phenyl ring can increase the solubility of the chromophores in common solvent considerably, the terminal amino group is a versatile functional group to link with other chromophores, and meanwhile, the $\mathrm{O}$ and $\mathrm{N}$ substituted ones can elevate the HOMO level.

Scheme 1. Synthesis of 6 and 7.

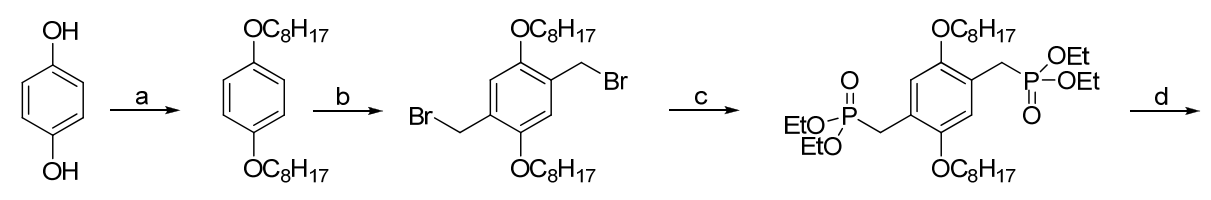

1

2

3

4
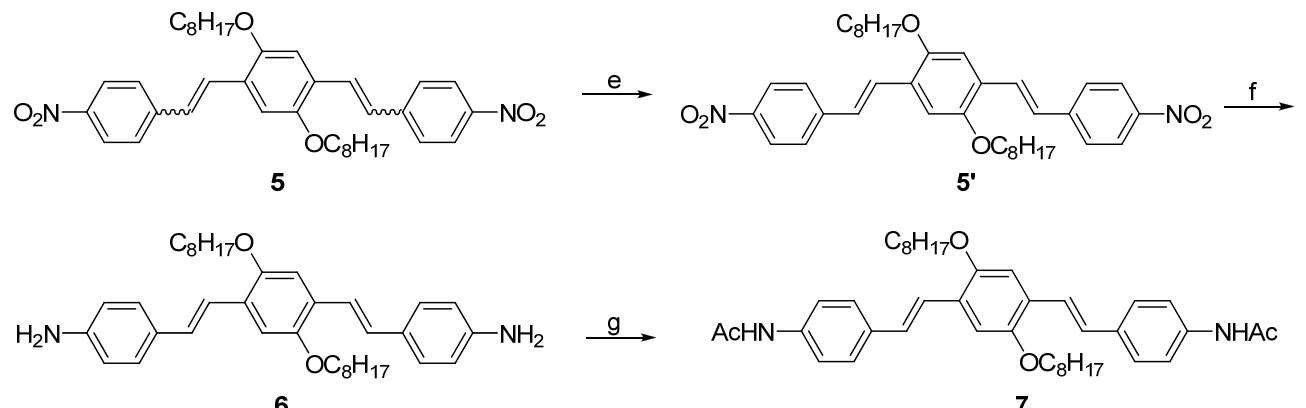

Reagents and conditions: (a): $\mathrm{KOH}, n-\mathrm{C}_{8} \mathrm{H}_{17} \mathrm{Br}$, DMSO, reflux, $80^{\circ} \mathrm{C}, 75 \%$; (b): $40 \% \mathrm{HBr}, \mathrm{HOAc}$, $\left(\mathrm{CH}_{2} \mathrm{O}\right)_{\mathrm{n}}$, reflux, 71\%; (c): $\mathrm{P}(\mathrm{OEt})_{3}$, reflux; (d) $t$-BuOK, 4-nitrobenzyladehyde, THF, $74 \%$ for two steps; (e) $\mathrm{I}_{2}$ (cat.), Tol., reflux, 95\%; (f) $\mathrm{SnCl}_{2} 2 \mathrm{H}_{2} \mathrm{O}, \mathrm{EtOH}, \mathrm{EtOAc,} \mathrm{83 \% ;} \mathrm{(g):} \mathrm{AcCl}_{2} \mathrm{Et}_{3} \mathrm{~N}, \mathrm{DMAP}$ $96 \%$. 
The synthetic strategy employed for the synthesis of 7 was based on the Horner-Emmons reaction. Hydroquinone was used as starting material, which was alkylated in DMSO with $\mathrm{C}_{8} \mathrm{H}_{17} \mathrm{Br}$ in the presence of $\mathrm{KOH}$, and then it was subsequently treated with conc. $\mathrm{HBr}$ and paraformaldehyde, to give a benzyl bromide derivative. Compound 3 was reacted with $\mathrm{P}(\mathrm{OEt})_{3}$ to give the phosphonate $\mathbf{4}$. After reaction of 4-nitrobenzyladehyde and the phosphonate 4, a mixture of cis and trans isomers was obtained. In order to get all trans product, a catalytic isomerization of the mixtures was performed in the presence of iodide in toluene to convert the cis isomers to compound 5'. A tin (II) chloride reduction of the nitro groups [17] afforded diamino substituted terphenyldivinyl derivative 6 . Compound $\mathbf{6}$ was subjected to a conventional acetylation process to give compound $\mathbf{7}$.

Moreover, to gain insight into the electronic properties of our target molecular, its molecular geometry was fully optimized at the B3LYP/6-31G level 10 using Gaussian 03 package. As shown in Figure 2, the contour of HOMO and LUMO of compound 6 was given after computational calculation. The HOMO and LUMO were condensed mostly on middle benzene ring, and the long alkyl chains were distributed symmetrically. The levels of HOMO and LUMO were $-4.41 \mathrm{eV}$ and $-1.20 \mathrm{eV}$, respectively.

Figure 2. HOMO and LUMO of 6 at the B3LYP/6-31G.
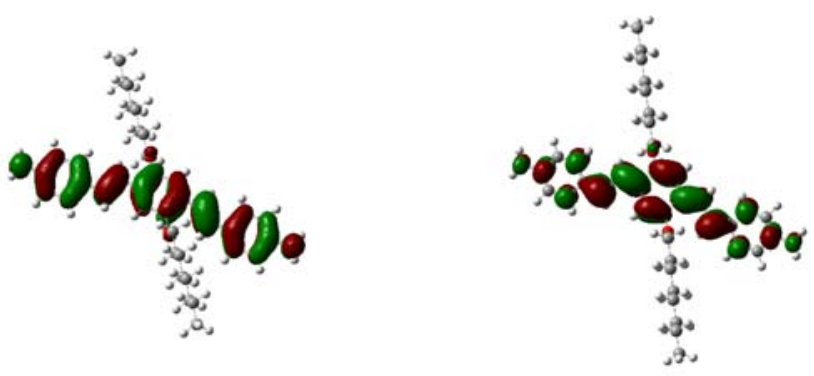

The absorption and emission spectrum were also evaluated. The absorption peak of compound 6 and 7 are at $401 \mathrm{~nm}$ and $397 \mathrm{~nm}$, and the max emission are at $466 \mathrm{~nm}$ and $458 \mathrm{~nm}$, respectively. This emission wavelength indicated that it can be cooperated with perylene moiety as donor [16].

Figure 3. The absorption and emission of 6 and 7 in $\mathrm{CH}_{2} \mathrm{Cl}_{2}$.

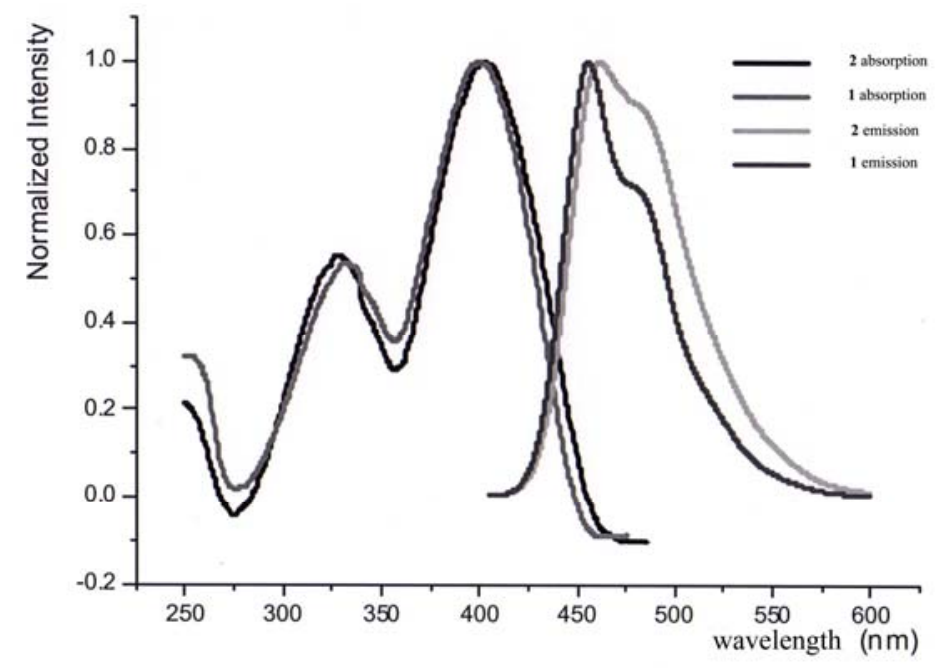




\section{Experimental}

\section{General}

The ${ }^{1} \mathrm{H}$-NMR and ${ }^{13} \mathrm{C}$-NMR data were recorded in $\mathrm{CDCl}_{3}$ solution with Bruker AM-200 or AM$400 \mathrm{MHz}$ spectrometers. The chemical shifts are reported in ppm relative to TMS or $\mathrm{CDCl}_{3}$. Column chromatography were generally performed on silica gel (200-300 mesh) eluting with petroleum ether:EtOAc (100:1-10:1 v/v) and TLC inspections on silica gel GF254 plates with petroleum ether:EtOAc ( 20:1-5:1 v/v ) if not noted otherwise.

1,4-bis(Octyloxy)benzene (2): Under Ar, a mixture of hydroquinone (55.0 g, $0.5 \mathrm{~mol}$ ), $\mathrm{KOH}$ (67.2 g, $1.2 \mathrm{~mol}$ ) and octyl bromide (251.0 g, $1.3 \mathrm{~mol})$ in DMSO $(400 \mathrm{~mL})$ was stirred for 48 hours at $80^{\circ} \mathrm{C}$. after the reaction completion and cooling, the reaction mixture was poured into water $(2000 \mathrm{~mL})$ with stirring, the precipitate was collected and washed with water $(300 \mathrm{~mL})$ and ether/petroleum ether $(1: 1$, $3 \times 50 \mathrm{~mL}$ ) and the product (125 g, 75\%) was used in the next step without further purification. ${ }^{1} \mathrm{H}$ NMR: 0.91 (t, J=6.6 Hz, 6H), 1.29-1.33 (m, 16H), 1.43-1.46 (m, 4H), 1.74-1.79 (m, 4H), 3.92 (t, $J=6.6 \mathrm{~Hz}, 4 \mathrm{H}), 6.84$ (s, 4H).

1,4-bis(Bromomethyl)-2,5-bis(octyloxy)benzene (3): A mixture of 1,4-bis(octyloxy)benzene (6, 33.4 g, $0.1 \mathrm{~mol})$, paraformaldehyde (10.8 g, $0.36 \mathrm{~mol})$, HOAc $(80 \mathrm{~mL})$ and $\mathrm{HBr}(40 \%, 50 \mathrm{~mL})$ was refluxed for 24 hours; after cooling, the precipitate was collected and washed with water. The compound (40 g, 71\%) was used for the next step without further purification. ${ }^{1} \mathrm{H}-\mathrm{NMR}$ : 0.93 (t, $\left.J=6.6 \mathrm{~Hz}, 6 \mathrm{H}\right), 1.32$ 1.37 (m, 16H), 1.50-1.53 (m, 4H), 1.84-1.87 (m, 4H), 3.98 (t, J=6.6 Hz, 4H), 4.54 (s, 4H), 6.87 (s, 2H).

Tetraethyl (2,5-bis(octyloxy)-1,4-phenylene)bis(methylene)diphosphonate (4): A mixture of compound 3 (5.0 g, 10mol) and triethyl phosphite $(4.1 \mathrm{~g}, 0.025 \mathrm{~mol})$ was refluxed for 12 hours, and then the volatiles were stripped off by oil pump. The residue of the desired diphosphonate 4 was used directly.

1,4-bis(4'-Nitrostyryl)-2,5-bis(octyloxy)-benzene (5): Under an atmosphere of Ar, t-BuOK (2.47 g, 22 mmol) was added portionwise at $0^{\circ} \mathrm{C}$ to a solution of the residue of $\mathbf{4}$ mentioned above dissolved in anhydrous THF (30 mL). The mixture was stirred at this temperature for $2 \mathrm{~h}$, then a solution of 4nitro-benzaldehyde (3.33 g, $22 \mathrm{mmol})$ in anhydrous THF $(10 \mathrm{~mL})$ was added. The reaction mixture was stirred at $0^{\circ} \mathrm{C}$ for 2 hours, and then at $25^{\circ} \mathrm{C}$ for an additional 4 hours. Finally the mixture was quenched with water, the volatiles were evaporated first, then the aqueous phase was extracted with ethyl acetate $(3 \times 50 \mathrm{~mL})$, The combined organic extracts were washed with brine $(2 \times 10 \mathrm{~mL})$, dried over anhydrous sodium sulfate and evaporated, the product (4.65 g, 74\%) after flash column chromatography was obtained as a mixture of cis and trans isomers 5.

(E,E)-1,4-bis(4'-nitrostyryl)-2,5-bis(octyloxy)-benzene (5'): To a solution of the crude compound 5 $(4.50 \mathrm{~g}, 7.1 \mathrm{mmol})$ in toluene $(75 \mathrm{~mL})$ was added $\mathrm{I}_{2}(90 \mathrm{mg}, 0.355 \mathrm{mmol})$, then the mixture was refluxed for 3 days and monitored by ${ }^{1} \mathrm{H}-\mathrm{NMR}$. After completion, the mixture was washed with sodium sulfite, water, brine $(10 \mathrm{~mL})$ and dried over anhydrous sodium sulfate. Purification by column 
chromatography afforded (E,E)-1,4-bis(4'-nitrostyryl)-2,5-bis(octyloxy)-benzene (5', $4.27 \mathrm{~g}, 95 \%)$ as a red solid. ${ }^{1} \mathrm{H}-\mathrm{NMR}: 0.88$ (t, $\left.J=6.8 \mathrm{~Hz}, 6 \mathrm{H}\right), 1.27-1.43(\mathrm{~m}, 16 \mathrm{H}), 1.51-1.57$ (m, 4H), 1.86-1.91 (m, 4H), 4.07 (t, $J=6.8 \mathrm{~Hz}, 4 \mathrm{H}), 7.12$ (s, 2H), 7.21 (d, $J=16 \mathrm{~Hz}, 2 \mathrm{H}), 7.61(\mathrm{~d}, J=8 \mathrm{~Hz}, 4 \mathrm{H}), 7.62$ (d, $J=16 \mathrm{~Hz}, 2 \mathrm{H})$, 8.21(d, $J=8 \mathrm{~Hz}, 4 \mathrm{H}) .{ }^{13} \mathrm{C}-\mathrm{NMR}: 14.56,23.06,26.64,29.65,29.71,29.72,32.12,69.44,110.42,123.78$, $126.34,126.43,126.59,127.53,143.82,146.03,150.84$.

(E,E)-1,4-bis(4'-aminostyryl)-2,5-bis(octyloxy)-benzene (6): To a solution of compound 5' (1.5 g 2.4 $\mathrm{mmol})$ in ethanol $(20 \mathrm{~mL})$ and ethyl acetate $(20 \mathrm{~mL}), \mathrm{SnCl}_{2}$ dihydrate $(15 \mathrm{~g}, 80 \mathrm{mmol})$ was added, and the reaction mixture was refluxed for 8 hours. After completion, water $(50 \mathrm{~mL})$ was added and the reaction mixture extracted with ethyl acetate $(3 \times 50 \mathrm{~mL})$. The combined organic extracts were washed successively with water and brine, dried over anhydrous sodium sulfate and evaporated, After purification by column chromatography to afford (E,E)-1,4-bis(4'-aminostyryl)-2,5-bis(octyloxy)benzene 6 (1.12g, 83\%) as red solid. ${ }^{1} \mathrm{H}-\mathrm{NMR}$ : 0.88 (t, $\left.J=7.2 \mathrm{~Hz}, 6 \mathrm{H}\right), 1.27-1.43$ (m, 16H), 1.51-1.57 (m, 4H), 1.86-1.91 (m, 4H), 3.74 (s, 4H), 4.03 (t, J=6.4 Hz, 4H), 6.65(dt, J=8.4 Hz, J=2 Hz, 4H), 7.03 (d, $J=16.8 \mathrm{~Hz}, 2 \mathrm{H}), 7.07$ (s, 2H), 7.26 (d, $J=16.8 \mathrm{~Hz}, 2 \mathrm{H}$ ), 7.33(dt, $J=8.4 \mathrm{~Hz}, J=2 \mathrm{~Hz}, 4 \mathrm{H}$ ); ${ }^{13} \mathrm{C}-\mathrm{NMR}$ : 14.60, 23.09, 23.66, 29.67, 29.78, 29.88, 32.15, 69.63, 110.03, 114.90, 119.59, 126.40, 127.30, 127.98, 128.38, 145.33, 150.24 .

(E,E)-1,4-bis(4'-Acetamidostyryl)-2,5-bis(octyloxy)-benzene (7): To a solution of compound 6 (568 mg, $1 \mathrm{mmol}), \mathrm{Et}_{3} \mathrm{~N}(1 \mathrm{~mL})$ and DMAP (12 mg, $\left.1 \mathrm{mmol}\right)$ in $\mathrm{CH}_{2} \mathrm{Cl}_{2}(10 \mathrm{~mL}), \mathrm{AcCl}$ (200 mg, $\left.2.5 \mathrm{mmol}\right)$ was added and the reaction mixture was stirred at room temperature and monitored by TLC. After completion of the reaction, the mixture was quenched with water and extracted with $\mathrm{CH}_{2} \mathrm{Cl}_{2}(3 \times 30$ $\mathrm{mL}$ ), then the combined organic extracts were washed successively with water, brine, dried over anhydrous sodium sulfate and evaporated, purification by column chromatography afforded compound 7 (626 mg, 96\%) as a red solid. ${ }^{1} \mathrm{H}-\mathrm{NMR}: 0.83$ (t, $\left.J=7.2 \mathrm{~Hz}, 6 \mathrm{H}\right), 1.17-1.38$ (m, 16H), 1.57-1.63 (m, 4H), 1.86-1.91 (m, 4H), 2.05 (s, 6H), 3.98 (t, J=6.4 Hz, 4H), 6.95(s, 2H), 7.42 (d, J=8.4 Hz, 4H), 7.43 (d, $J=16 \mathrm{~Hz}, 2 \mathrm{H}), 7.56$ (d, $J=16 \mathrm{~Hz}, 2 \mathrm{H}), 7.64(\mathrm{~d}, J=8.4 \mathrm{~Hz}, 4 \mathrm{H}), 9.99(\mathrm{~s}, 2 \mathrm{H}) ;{ }^{13} \mathrm{C}-\mathrm{NMR}: 14.62,23.19$, 23.64, 24.11, 29.67, 29.78, 29.88, 32.15, 69.67, 110.17, 115.10, 120.35, 126.58, 127.33, 127.98, 128.61, 145.96, 151.82, 168.91 .

\section{Conclusions}

In summary, we have designed and synthesized a new diamino substituted Oligophenylvinyl chromophore (E,E)-1,4-bis(4'-aminostyryl)-2,5-bis(octyloxy)-benzene (6) and its derivative (E,E)-1,4bis(4'-acetamidostyryl)-2,5-bis(octyloxy)-benzene (7). At the same time, we have examined the HOMO and the LUMO levels after theoretical calculations. Further application is in progress.

\section{Acknowledgements}

Financial support from Program for Excellent Young Talents in Northwest A\&F University (2111020712) as well as the National Natural Science Foundation of China (20802058) is greatly appreciated. I am indebted to Professor Hou and Professor Yin for their detailed discussions on the utilization of Gaussian for calculations. 


\section{References and Notes}

1. Baik, C.; Kim, D.; Kang, M.S.; Kang, S.O.; Ko, J.; Nazeeruddin, M.K.; Gratzel, M. Organic dyes with a novel anchoring group for dye-sensitized solar cell applications. J. Photochem. Photobiol. A 2009, 201, 168-174.

2. Yum, J.H.; Hagberg, D.P.; Moon, S.J.; Karlsson, K.M.; Marinado, T.; Sun, L.C.; Hagfeldt, A.; Nazeeruddin, M.K.; Gratzel, M. A Light-Resistant Organic Sensitizer for Solar-Cell Applications. Angew. Chem. Int. Edit. 2009, 48, 1576-1580.

3. Yum, J.H.; Jung, I.; Baik, C.; Ko, J.; Nazeeruddin, M.K.; Gratzel, M. High efficient donoracceptor ruthenium complex for dye-sensitized solar cell applications. Energy Environ. Sci. 2009, 2, 100-102.

4. Tang, C.W.; Vanslyke, S.A. Organic electroluminescent diodes. J. Appl. Phys. 1987, 51, 913-915.

5. Mason, M.G.; Hung, L.S.; Tang, C.W.; Lee, S.T.; Wong, K.W.; Wang, M. Characterization of treated indium-tin-oxide surfaces used in electroluminescent devices. J. Appl. Phys. 1999, 86, 1688-1692.

6. Jin, J.Y.; Jin, Z.Z.; Xia, Y.; Zhou, Z.Y.; Wu, X.; Zhu, D.X.; Su, Z.M. Design and synthesis of 1,4bis[4-(1,1-dicyanovinyl)styryl]-2,5-bis(alkoxy)benzenes as red organic electroluminescent PPV analogs. Polymer 2007, 48, 4028-4033.

7. Cacialli, F.; Feast, W.J.; Friend, R.H.; de Jong, M.; Lovenich, P.W.; Salaneck, W.R. Synthesis and characterisation of poly(distyrylbenzene-block-hexa(ethylene oxide)) and its fluorinated analogue-two new block copolymers and their application in electroluminescent devices. Polymer 2002, 43, 3555-3561.

8. Kimoto, A.; Masachika, K.; Cho, J.S.; Higuchi, M.; Yamamoto, K. Synthesis and electroluminescence properties of novel main chain poly(p-phenylenevinylene)s possessing pendant phenylazomethine dendrons as metal ligation sites. Chem. Mater. 2004, 16, 5706-5712.

9. Kimura, M.; Sato, M.; Adachi, N.; Fukawa, T.; Kanbe, E.; Shirai, H. Poly(p-phenylene vinylene)s wrapped with 1,3,5-phenylene-based rigid dendrons. Chem. Mater. 2007, 19, 2809-2815.

10. Wu, C.Y.; Tian, D.H.; Feng, Y.; Polak, P.; Wei, J.J.; Sharp, A.; Stankoff, B.; Lubetzki, C.; Zalc, B.; Mufson, E.J.; Gould, R.M.; Feinstein, D.L.; Wang, Y.M. A novel fluorescent probe that is brain permeable and selectively binds to myelin. J. Histochem. Cytochem. 2006, 54, 997-1004.

11. Abbel, R.; Grenier, C.; Pouderoijen, M.J.; Stouwdam, J.W.; Leclere, P.; Sijbesma, R.P.; Meijer, E.W.; Schenning, A. White-Light Emitting Hydrogen-Bonded Supramolecular Copolymers Based on pi-Conjugated Oligomers. J. Am. Chem. Soc. 2009, 131, 833-843.

12. Shanks, D.; Preus, S.; Qvortrup, K.; Hassenkam, T.; Nielsen, M.B.; Kilsa, K. Excitation energy transfer in novel acetylenic perylene diimide scaffolds. New J. Chem. 2009, 33, 507-516.

13. Takahashi, M.; Ichihashi, Y.; Nishizawa, N.; Ohno, S.; Fujit, N.; Yamashita, M.; Sengoku, T.; Yoda, H. Construction of light-harvesting reverse micelles in nanoscopic dimensions. J. Photoch. Photobio. A 2009, 203, 56-63.

14. Wang, H.Y.; Pu, K.Y.; Huang, S.; Liu, F.; Peng, B.; Wei, W. Alternating copolymers based on perylene bisimide and oligo(p-phenylene ethynylene) units: Synthesis, characterization, and photoinduced energy and electron transfer processes of a new class of donor-acceptor systems. React. Funct. Polym. 2009, 69, 117-123. 
15. Liu, Y.; Yang, C.H.; Li, Y.J.; Li, Y.L.; Wang, S.; Zhuang, J.P.; Liu, H.B.; Wang, N.; He, X.R.; Li, Y.F.; Zhu, D.B. Synthesis and photovoltaic characteristics of novel copolymers containing poly(phenylenevinylene) and triphenylamine moieties connected at 1,7 bay positions of perylene bisimide. Macromolecules 2005, 38, 716-721.

16. Syamakumari, A.; Schenning, A.P.H.J.; Meijer, E.W. Synthesis, optical properties, and aggregation behavior of a triad system based on perylene and oligo(p-phenylene vinylene) units. Chem. Eur. J. 2002, 9, 3353-3361.

17. Bellamy, F.D.; Ou, K. Selective reduction of aromatic nitro compounds with stannous chloride in non acidic and non aqueous medium. Tetrahedron Lett. 1984, 25, 839-842.

Sample Availability: Samples of the compounds $\mathbf{1}$ to $\mathbf{7}$ are available from the authors.

(C) 2009 by the authors; licensee Molecular Diversity Preservation International, Basel, Switzerland. This article is an open-access article distributed under the terms and conditions of the Creative Commons Attribution license (http://creativecommons.org/licenses/by/3.0/). 